\title{
Religious Diversity and Political Change in Thailand
}

\author{
Petcharat Lovichakorntikul, *John Walsh \\ Shinawatra University, Bangkok, Thailand \\ *jcwalsh100@hotmail.com
}

\begin{abstract}
Thailand continues to undergo a process of political modernization, moving from a feudal to a fully-fledged and modernized capitalist society. This is a process that has involved numerous missteps and backward turns - most recently the 2006 military coup and the 2010 massacres - and the dissolution of previously existing cultural and social bonds. Marketization of all regions of the country has brought about changes in land ownership, social relations and gender relations but has not, as yet, brought about changes in religious beliefs or in the relationships between people of different belief systems. The majority Buddhist philosophy has been invigorated by emphasis placed on figures such as the goddess Guan Yin, who is eminently appropriate for the age of plenty, while animist hill tribes people incorporate new ways of life into a flexible and accommodating belief system. Only in the southern provinces bordering Malaysia, where the majority of people are ethnic Malay Muslims, is there a division between people based on religion. A faction of people in the border regions have been agitating for autonomous rule or, at least, an end to unfair and unpleasant treatment by high-handed representatives of the Thai state and their mandate to enforce the longstanding triumvirate of Thai language, Buddhist belief and respect for the monarchy as defining characteristics of citizens. Agitation has led to acts of terrorism and suppression including atrocities on both sides. These divisions are not reflected in any other part of the country, although plenty of other symptoms of division are.
\end{abstract}

\section{Keywords: Religious diversity, political change, Thailand}

\section{Introduction}

The majority of Thai people, well in excess of $90 \%$, profess Buddhism as their religion. Thai Buddhism is Theravadin in nature, which places an emphasis on doing good deeds ('tam boon') as a means of approaching enlightenment ('nibbana') and the early morning alms-giving to monks as a form of tam boon is a common sight throughout the country. The role of the monks as guardians and transmitters of valuable information is important in Thai society as it is throughout most of the Mekong Subregion. Most Thai men will be ordained as a monk for at least a temporary period during their lives. Women may become Bhikkunis (nuns) and live by the prescribed eight precepts but that status is not formally recognized. For more than a century, uniformity of belief has been stressed as an essential part of Thai citizenship as part of a triumvirate of institutions: central Thai dialect, Buddhism and respect for the monarchy. Opposition or even perceived opposition to this formula can be very problematic for the individual involved.

Two factors within Buddhism itself have acted to promote regularity of belief. The first was Buddhist modernism, which began as a reaction against the colonization of neighbouring Burma (Myanmar), Malaya (Malaysia), Laos and Cambodia. Most important cultural, political, social and economic institutions were modernized along foreign, primarily western lives. However, embracing Christianity was a wholly unacceptable step too far and would have represented an admission of failure within Thai society which could not be made. Instead, it was determined that Buddhism, which had become adorned by a wide range of accretions, including beliefs in magical and supernatural powers quite unrelated to the dhamma of the Buddha. Efforts were made, therefore, to return to a purer form of belief that more closely related to the original, core Theravadin texts. To promote conformity with this approach, pamphlet production and distribution began to take place on a large-scale and some venerable monks have become well-known as authors of such tracts. The second movement within Buddhism has been the attempt to control the sangha - the organization of ordained monks. The great majority of the wats and the monks who reside in them belong to the Mahanikai sect, which has a tradition of decentralization and, hence, more likelihood for variations in belief. However, first under King Rama V Chulalongkorn (1853-1910) at the start of the twentieth century and then under the military dictatorship of Field Marshall Sarit (195863), the leadership of the sangha was given to the numerically much smaller monarchist Thammayut sect 
as a means of promoting the monarchy and making more explicit the link between temporal power and overt virtue.

Nevertheless, Buddhism in Thailand remains very diverse in nature because of the importation of foreign elements and practices and because of the syncretic nature of Thai belief. Many if not all Thai people incorporate a variety of animist beliefs in their world view and those with Chinese ancestry may also incorporate Chinese religious elements and practices into their overall cosmology. One very notable example of this is the rise of the Guan Yin (Guan Im) goddess, whose likeness is found in a wide range of wats across the country but particularly in Bangkok. Guan Yin has become associated with aspirational middle class values such as family harmony at a time of transition, good health and regular income streams. Followers of the goddess tend to demonstrate their loyalty by giving up the consumption of beef and this has been taken up with such enthusiasm that the once-thriving beef noodles industry has collapsed and American fast food chains have been obliged to vary their product offerings or else to withdraw from the market. The state, too, has employed syncretic approaches to its use of religion as a means of promoting its own interests. This is particularly true in the case of Brahmanical rituals and ceremonies such as the annual buffalo-ploughing event that is used to foretell agricultural conditions prevalent in the Kingdom for the forthcoming year. Brahmanical rituals are known to be closely tied to the role and nature of kingship and also contain the sub-text of caste and hierarchies (Kuanpoonpol, 1990).

\section{Popular Superstition}

Globalization is translated in Thai as 'lukanuwat' - which refers to a process of becoming more engaged with the material world. This, globalization, is generally viewed with suspicion because worldliness is antithetical to the Buddhist aspiration to nibbana through the annihilation of the ego and is also contrary to the sermons and teachings of just about every monk in the public eye. Yet globalization is the process that has been embraced by the Thai state as part of the drive towards rapid economic development and modernization and this has led to one of a series of contradictions in Thai society. On the one hand, people as whole enjoy the benefits of globalisation and are involved in a capitalist system aimed at providing a greater accumulation of goods and capital; on the other hand, people are regularly reminded of their obligation that can b resolved in part through the creation of goof karma from tam boon; good karma can outweigh an accumulated stock of bad karma without eradicating it. Consequently, as people are forced to engage in the production of bad karma on a daily basis because of the involvement with lukanuwat, they can outweigh the involvement with the tawdry mundane world through the judicious creation of good karma. However, some people take a different approach and instead look to use their knowledge of magical and sacred knowledge to enlarge their stock of worldly goods. Perhaps through the mediation of helpful spirits, they hope to be able to unlock secret knowledge or foretell the future so as to win the lottery or obtain a better job or have more success with personal relationships. There is also a reverse process by which things of the world (e.g. automobiles) may be brought into the realm of the sacred by having them blessed and marked with sacred symbols so that their own spirit will protect the people who use and rely on them.

It is usually assumed that these kinds of activities are related to and indeed representative of the syncretic nature of Thai religious belief, in which disparate belief systems can be yoked together to make a coherent whole without cognitive dissonance. However, it has also been argued that a better way to understand Thai popular religion is as a process of hybridization, in which one belief system may have been imposed on a subject population through a process of colonization; hybridization then represents a degree of agency on the behalf of the colonised in reinventing their religious beliefs in formats which will not be suppressed (Kitiarsa, 2012: 11-6).This aspect of religion in Thailand is evident in recent political change, which has used some elements of popular religion in mass pro-democracy protests - to set against those divergent elements used by the authoritarian elite, such as the presence of HinduBrahmanist images used to demarcate certain sacred locations in the city centre, which were used in part as a pretext for the use of state violence on a large scale.

\section{Religious Diversity in the South of Thailand}

Three provinces in the south of Thailand, Yala, Narathiwat and Pattani, have a population which are predominantly ethnically Malay Muslims and live in an area that was once an independent state known as Patani (Syukai, 1985). There are other groups of Muslims living in Thailand but these tend to live in 
smaller communities and as minorities which have been influenced by the prevailing Buddhist and Brahmanical practices (Scupin, 1998). By contrast, the Muslims of southern Thailand live as part of the majority, belong to a wider Malay-Indonesian cultural and religious ethos and speak a language of their own, Jawai, which combines classic Malay with Arabic script. The border between Thailand and what is now Malaysia has through most of history been porous in nature and this was brought into sharp focus during the long Emergency period (1948-60) - the Communist insurgency in Malaysia and potential uprising in Thailand. The ability of agents to cross the border very conveniently became evident. For decades, it has been the practice of the Thai bureaucracy to send officials out of favour to the south as a form of punishment and, as a result, they sometimes instituted unfair administrations in the region. This view, which is commonly propounded by foreign observers, is countered by the local Thai view that customarily sees the south as an area of outsiders wrongly trying to rebel against the rightful and righteous central rule (Aphornsuvan, 2008). The result, in any case has been a rather confused campaign of violence against centralised rule and for autonomy of some sort has been launched by different sets of people. There has been a series of attacks against representatives of the central state: security forces, schools and school teachers, Buddhist monks and civil servants. Since there is no central organization behind the insurgency, so it appears there has been no issuance of a coherent manifesto or list of demands and as the Thai state has refused to countenance any kind of discussion of the possibility of autonomy (Jitpirornsiri and McCargo, 2008), the thousands of death that have resulted seem set only to increase.

\section{Political Change}

Politics in Thailand in the twenty-first century has witnessed a struggle by the masses of the people, organized by capitalist interests as part of an unprecedentedly wide coalition of interests aimed at wresting control of important institutions (parliament included) from the unaccountable authoritarian elites that have historically controlled them. The people have repeatedly demonstrated their ability to support political groupings able to win democratic elections with wide margins. In response, the elites have responded by military coup, convenient judicial dissolutions of victorious parties and banning of successful politicians as a means of maintaining the status quo. Numerous factions and groups have been involved in this process, although it is conventional and convenient to narrow them down to a Manichean duality. In this duality, the political struggle is matched by a cosmological struggle between the Brahmanical rituals and ceremonies of the Bangkok elite against the popular superstitions of the Thai people of the regions. One particularly striking example of this was the beginning of the mass prodemocracy demonstrations mounted against the Abhisit Vejjajivaregime, which had been ushered in by a set of shabby accommodations brokered by the military after Abhisit's party had again been defeated in free and fair elections. The demonstrators, who had for some years colonized the colour red, voluntarily donated their blood, which was amalgamated into a large tub and kept for some later use. That the demonstrations ended with a series of massacres by the military against the pro-democracy demonstrators only reinforced the realization that, in the minds of many of those involved, the struggle was taking place on more than just the mundane plane.

\section{Conclusion}

Animist or popular religious beliefs are highly prevalent in contemporary Thailand and the celebration of the practices in so many representations of popular media - including the very popular 'lakhon' or soap operas -indicates their importance to people in navigating the trials and tribulations of daily life. They have a particular importance in helping to determine the future: in a pre-modern world in which individuals have little ability to control the overwhelming power of nature and the reach of monarchs and officials, magical or religious powers act as a means of empowering the individual against the world, particularly if it has the benefit of being sanctioned or even promoted by the local monks. In the modern world, the power of the forces of globalization represents a different but equally overwhelming series of powers that must be contended with and assistance is provided again by secret knowledge and practice. Such knowledge and practice is, theoretically at least, open to everyone and hence has implications for democratization. It would not be surprising if people concluded that, given the apparently uncontrollable forces seemingly arrayed against them, they feel constrained to call upon higher powers to try to give them the rights that they have been promised by various high-ranking interests. The sangha is one of the institutions that are divided into two or more factions with respect to the division of power and state resources, while the army is another. It is almost impossible for people from the outside to identify the relative importance of different factions without either detailed network connections or knowledge 
provided by some super-normal means. Religion has, at least according to some interpretations, throughout history provided an opportunity for people to understand the motives of super-normal people and institutions and to hope to be able to influence them.

\section{References}

Aphornsuvan, T. (2008). Origins of Malay Muslim 'Separatism' in Southern Thailand, in Michael J. Montesano and Patrick Jory, eds., Thai South and Malay North: Ethnic Interactions on a Plural Peninsula (Singapore: NUS Press, 2008), 91-123.

Jitpirornsiri, S. \& McCargo, D. (2008). New Governance Proposals for Thailand's Southern Region. Contemporary Southeast Asia, 30(3), 403-28.

Kitiarsa, P. (2012). Mediums, Monks, and Amulets: Thai Popular Buddhism Today (Chiang Mai: Silkworm Books).

Kuanpoonpol, P. (1990). Court Brahmans of Thailand and the Celebration of the Brahmanic New Year. Indo-Iranian Journal, 33(1), 31-51.

Scupin, R. (1998). Muslim Accommodation in Thai Society. Journal of Islamic Studies, 9(2), 229-58.

Syukai, I. (1985). History of the Malay Kingdom of Patani (Athens, OH: Ohio University), translated by Conner Bailey and John N. Miksic. 